Berkala Ilmu Perpustakaan dan Informasi, Vol. 16, No. 2, Desember 2020, Hal. 170-183 DOI: 10.22146/bip.v16i1.770

ISSN 1693-7740 (Print), ISSN 2477-0361 (Online)

Tersedia online di https://journal.ugm.ac.id/v3/BIP

\title{
Pemanfaatan portal basis data daring dalam validasi nama ilmiah jenis dan suku tumbuhan
}

\author{
I Putu Gede P. Damayanto ${ }^{1}$, Fandri S. Fastanti ${ }^{2}$, dan Syadwina H. Dalimunthe ${ }^{3}$ \\ ${ }^{1,2,3}$ Herbarium Bogoriense, Pusat Penelitian Biologi, Lembaga Ilmu Pengetahuan Indonesia (LIPI) \\ Jl. Raya Jakarta-Bogor, km 46, Cibinong, Kabupaten Bogor, Jawa Barat 16911 \\ e-mail: parlida.damayanto.tab@gmail.com
}

Naskah diterima: 2 Oktober 2020, direvisi: 10 November 2020, disetujui: 16 November 2020

\begin{abstract}
ABSTRAK
Pendahuluan. Kajian mengenai validasi nama ilmiah jenis dan suku tumbuhan masih terbatas. Penelitian ini bertujuan untuk menyediakan informasi tentang proses validasi nama ilmiah pada tingkat jenis dan suku.

Metode penelitian. Data dikumpulkan dari basis data portal daring mengenai nama ilmiah jenis dan suku pada tumbuhan. Data dianalisis secara deskriptif-naratif.

Hasil dan Pembahasan. Validasi nama ilmiah jenis dan suku pada tumbuhan dapat dilakukan melalui penelusuran publikasi terkini dan memanfaatkan portal basis data daring seperti IPNI, POWO, Tropicos, The Plant List, dan GBIF. IPNI dan The Plant List memberikan informasi lebih banyak tentang nama jenis tumbuhan dibandingkan dengan portal lain. POWO dan GBIF memberikan informasi tentang status nama tumbuhan yang dilengkapi dengan foto tumbuhan, spesimen, dan peta persebarannya. Tropicos menampilkan nama suku yang telah mengikuti klasifikasi terbaru APG IV.

Kesimpulan dan Saran. Validasi nama ilmiah jenis dan suku melalui portal basis data daring merupakan cara tercepat untuk melakukan validasi, namun demikian, validasi melalui publikasi revisi taksonomi tumbuhan terkini merupakan cara yang paling direkomendasikan. Validasi dapat diawali dengan memanfaatkan portal basis data daring dan selanjutnya dikonfirmasi dengan melakukan penelusuran publikasi revisi taksonomi tumbuhan terkini.
\end{abstract}

Kata kunci: nama ilmiah; portal basis data daring; taksonomi; tumbuhan; validasi

\section{ABSTRACT}

Introduction. The study of the validation of scientific names of plant type and family level is limited. This study aims to provide information on the process of scientific name validation on plant type and family level.

Data Collection Method. Data were collected from online portal databases covering the scientific name of plant family. Data was analyzed by conducting a descriptive-narrative approach

Results and Discussion. Validation of the scientific name of plant type and family level can be conducted by searching the latest publications through the online database portals such as IPNI, POWO, Tropicos, The Plant List, and GBIF. IPNI and The Plant List provide more information about species names compared to others. POWO and GBIF provide the status of the plant names and complemented with photographs of the plants, specimens, and distribution maps. Tropicos provides names of families according to the latest APG IV classification.

Conclusion. Validation through the online portal database is the fastest way, however, validation through the publication of the latest plant taxonomy revision publications is recommended. Validation can be initiated by using the online database portals and then confirmed by tracking the latest revised plant taxonomy publications.

Keywords: scientific name; online database portal; taxonomy; plant; validation 


\section{A. PENDAHULUAN}

Indonesia merupakan negara dengan keanekaragaman hayati tinggi dan memiliki sekitar 20.000 jenis tumbuhan tinggi berbunga (Pullaiah dkk., 2015). Laporan terkini menyatakan bahwa terdapat 31.750 jenis tumbuhan dan jamur di Indonesia (Retnowati \& Rugayah, 2019). Seluruh jenis tumbuhan dan jamur yang ditemukan telah diberi nama secara ilmiah. Nama ilmiah merupakan pembuka khazanah ilmu pengetahuan. Penamaan ilmiah suatu makhluk hidup bertujuan untuk menyediakan referensi dan memfasilitasi komunikasi ilmiah mengenai makhluk hidup tersebut. Penamaan tersebut harus dipahami secara universal, presisi dan stabil (Turland, 2019) sehingga dapat mempermudah penelusuran pustaka secara akurat dalam kegiatanpenelitian(Bennett\&Balick, 2014).

Nama umum atau lokal dari suatu makhluk hidup penting dalam kehidupan sehari-hari, tetapi tidak cukup akurat secara ilmiah (Bennett \& Balick, 2014). Penamaan berdasarkan nama lokal dapat menyebabkan kekacauan dalam komunikasi ilmiah. Setiap daerah dapat memberikan nama lokal yang berbeda untuk satu jenis tumbuhan yang sama. Sebagai contoh, gelinggan, galuga, kesumba atau pacar keling merupakan nama lokal tumbuhan untuk jenis Bixa orellana L. Sementara itu, nama lokal tumbuhankumiskucing digunakan pada duajenis tumbuhan berbeda, Cleome speciosa Raf. dan Orthosiphon aristatus (Blume) Miq. Contohcontoh tersebut dapat memunculkan ketidakjelasan dankebingungan akan suatunama tumbuhan. Untuk itu, penamaan ilmiah terutama untuk tumbuhan, jamur dan alga, telah diatur dan disepakati secara internasional. Setiap lima hingga enam tahun sekali, aturan ini diperbarui sesuai dengan perkembangan zaman. Aturan penamaan ilmiah untuk tumbuhan, jamur dan alga yang terkini dikenal dengan "International Code of Nomenclature for Algae, Fungi, and Plants" atau lebih dikenal dengan istilah "Shenzhen Code"(Turlanddkk.,2018).

Nama ilmiah jenis dan suku bersifat dinamis dalam taksonomi tumbuhan. Akibat perubahan konsep jenis, nama ilmiah jenis tumbuhan dapat diubah atau direvisi sesuai bukti-bukti ilmiah terbaru yang ditemukan. Sebagai contoh, bambu anggota marga Nastus awalnya dilaporkan terdiri dari satu marga bambu yang tumbuh tersebar mulai dari Madagaskar, Pulau Reunion hingga Asia Tenggara (kawasan Malesia). Berdasarkan bukti molekuler terbaru, diketahui bahwa terdapat dua kelompok berbeda Nastus, yaitu kelompok Nastus kawasan Malesia dan kelompok Nastus kawasan Madagaskar dan Pulau Reunion(Chokthaweepanich, 2014; Wong dkk., 2016; Zhou dkk., 2017). Widjaja \& Wong (2016) kemudian memberikan nama kombinasi baru untuk sebagian besar anggotajenis Nastus di kawasan Malesia. Salah satu jenis Nastus di kawasan Malesia yang awalnya bernama Nastus schmutzii S.Dransf. (Dransfield, 1980), kinitelah berubah nama menjadi Chloothamnus schmutzii (S.Dransf.) Widjaja (Widjaja \& Wong, 2016). Setiap komunitas ilmiah yang akan mengkomunikasikan entitas bambu $N$. schmutzii harus menggunakan nama terkininya, yaitu $C$. schmutzii, karena nama terakhir ini merupakan namayangyang diterimasecarailmiah.

Di sisi lain, perubahan konsep pada suku tumbuhan juga dapat terjadi. Oleh karena itu, penamaan untuk tingkat suku tumbuhan atau tingkatan lain di atasnya sebaiknya mengikuti hasil klasifikasi terkini yaitu The Angiosperm Phylogeny Group (APG, 2016). Sebagai contoh, pada marga Durio (durian-durianan) dan Gossypium (kapuk-kapukan), awalnya digolongkan ke dalam suku Bombacacae. Berdasarkan pengelompokan terbaru, margamarga tersebut dipindahkan ke suku Malvaceae (Stevens, 2001; APG, 2016). Perubahan takson ini juga wajib diikuti selama perubahan tersebut mengacupada aturan penamaan yang disepakati.

Perubahan nama jenis dan suku tumbuhan merupakan hal yang sering terjadi dalam kajian taksonomi tumbuhan. Kegiatan validasi perlu dilakukan untuk menjaga keakuratan dan kekinian nama jenis dan suku tumbuhan. Validasi nama jenis dan suku tumbuhan merupakan sebuah proses verifikasi nama ilmiah yang diterima (accepted) saat ini. Validasi merupakan kegiatan rutin yang dilakukan seorang peneliti dan kurator taksonomi sehingga memerlukan sumber acuan yang komprehensif dalam studi kepustakaannya.

Kajian mengenai validasi nama ilmiah jenis dan suku tumbuhan perlu dilakukan karena 
informasi tersebut belum diketahui secara luas dan masih ada penelitian yang menggunakan nama ilmiah tumbuhan yang tidak diterima saat ini. Sebagai contoh, terdapat beberapa penelitian terkini yang masih menggunakan nama Sauropus androgynus (L.) Merr. untuk merujuk nama ilmiah tumbuhan daun katuk (Anwar \& Wahyuni, 2020; Arisandy \& Triyanti, 2020; Fakhrizal \& Saputra, 2020; Fikri \& Purnama, 2020; Kurniawan dkk., 2020; Santoso dkk., 2020; Syhadat, 2020; Triananinsi dkk., 2020). Kenyataannya kini, nama jenis $S$. androgynus sudah tidak valid lagi karena telah direvisi pada tahun 2012 menjadi Breynia androgyna (L.) Chakrab. \& N.P.Balakr (Chakrabarty \& Balakrishnan, 2012). Di sisi lain, kajian mengenai pemanfaatan basis data daring dalam validasi nama ilmiah jenis dan suku tumbuhan belum pernah dilakukan. Tulisan ini bertujuan untuk memberikan informasi dasar mengenai tahapan yang dilakukan dalam validasi nama ilmiah jenis dan suku pada tumbuhan. Hasil kajian ini diharapkan dapat menyediakan rekomendasi dalam melakukan validasi nama ilmiah jenis dan suku tumbuhan. Dalam ilmu informasi, tulisan ini mengungkap sumber data daring terbuka (online open data resources) yang terpercaya dan mudah diakses untuk dimanfaatkan oleh masyarakat secara ilmiah.

\section{B. TINJAUAN PUSTAKA Klasifikasi Tumbuhan}

Setiap jenis tumbuhan telah dikelompokkan atau diklasifikasikan secara ilmiah ke dalam suatu tingkatan (taksa) mengikuti hierarki untuk memudahkan dalam mempelajari tumbuhan (dan juga makhluk hidup lainnya). Gagasan dari sistem klasifikasi pada tumbuhan adalah mengelompokkan tumbuhan dalam suatu sistem agar memudahkan dalam penggunaan dan mempelajarinya. Pengelompokan dilakukan dengan menganalisis bukti ilmiah secara multidisiplin, yakni pengamatan ciri morfologi, sitologi, anatomi, metabolit, molekuler hingga penelusuran pustaka (ACB, 2011).

Tingkatan takson dalam klasifikasi tumbuhan setidaknya berturut-turut terdiri dari yang terendah hingga tertinggi, yaitu forma, varietas, jenis, marga, suku, bangsa, kelas, dan divisi (Davis \& Heywood, 1963). Setiap takson tersebut dapat memiliki anak takson. Sifat-sifat yang dijadikan dasar dalam kegiatan klasifikasi berbeda-beda tergantung dari penyusun klasifikasi dan tujuan yang ingin dicapai. Taksa yang terdapat pada tingkat lebih rendah umumnya mempunyai kesamaan sifat lebih banyak daripada taksa yang terdapat pada tingkat di atasnya. Kategori anak taksa antara jenis dan suku paling sering digunakan dalam publikasi ilmiah yang melibatkan entitas tumbuhan.

Sistem klasifikasi, khususnya pada tumbuhan berbunga kini menggunakan sistem klasifikasi Angiosperm Phylogeny Group IV atau disingkat APG IV (APG, 2016). Klasifikasi sistem APG IV ini merupakan versi keempat dari sistem klasifikasi tumbuhan berbunga modern yang sebagian besar pengelompokkannya dilengkapi dengan data molekuler (karakter DNA tumbuhan). APG IV merupakan pemutakhiran dari sistem klasifikasi APG sebelumnya, yaitu APG III (APG, 2009), APG II (APG, 2003) dan APG I (APG, 1998). Contoh klasifikasi pada durian yang mengikuti APG IV yaitu bangsa: Malvales, suku: Malvaceae, marga: Durio, jenis Durio zibethinus L (Stevens, 2001). Sebelumnya, D. zibethinus termasuk ke dalam suku Bombacaceae (Kostermans, 1958).

\section{Nama Ilmiah Jenis dan Suku pada Tumbuhan}

Semua jenis tumbuhan di dunia diupayakan oleh komunitas ilmiah untuk diberi nama jenis secara ilmiah. Nama ilmiah merupakan kunci untuk membuka informasi suatu taksa yang dituju. Penamaan ilmiah tumbuhan bertujuan untuk menyediakan referensi dan memfasilitasi komunikasi ilmiah mengenai tumbuhan di seluruh dunia. Penamaan tersebut harus dipahami secara universal, presisi dan stabil (Turland, 2019). Nama lokal tumbuhan dengan berbagai bahasa daerah tidak memenuhi syarat universal, presisi dan stabil karena nama tersebut bersifat lokal dan banyak nama lokal yang sama diberikan pada dua atau lebih tumbuhan yang berbeda jenis, atau bahkan sebaliknya. Nama lokal biasanya tidak 
digunakan dalam dunia ilmiah karena sering kali menyebabkan kerancuan penafsiran meski makhluk hidup yang dimaksud adalah sama. Meski demikian, penggunaan nama lokal yang ditambahkan dalam deskripsi jenis dapat menambah wawasan pembaca.

Nama ilmiah merupakan nama yang diberikan kepada setiap takson tumbuhan yang berlaku secara universal (KBBID, 2020), baik itu menunjukkan tingkat jenis maupun suku. Nama ilmiah diberikan pada saat mendeskripsikan jenis baru maupun karena adanya perubahan konsep takson tertentu. Nama ilmiah jenis baru diterbitkan pada artikel dalam jurnal ilmiah yang telah memiliki international standard book number (ISBN) atau international standard serial number (ISSN) (Turland, 2019) serta mudah diakses melalui media elektronik. Nama ilmiah diberikan oleh penulis (author), yakni orang (atau sekelompok orang) yang mendeskripsikan dan memberikan nama pada takson tertentu. Inisial nama author tersebut akan dicantumkan berdampingan dengan nama ilmiah jenis atau tingkatan taksa lain yang dipublikasikan. Sebagai contoh, Carolus Linnaeus, ilmuwan asal Swedia yang pertama kali mengemukakan sistem binomial nomenclature pada 1753 (Müller-Wille, 2020), telah memberikan nama ilmiah pada ribuan jenis tumbuhan dan hewan. IPNI (2020) dan Tropicos (2020) mencatat ada sekitar 10.500 jenis tumbuhan yang telah dipublikasikan oleh Linnaeus dengan kode namanya disingkat "L.", salah satunya, yaitu cempaka kuning, Michelia champaca L. (Linnaeus, 1753). Adanya perubahan konsep jenis, maka M. champaca kemudian direvisi menjadi Magnolia champaca (L.) Baill. ex Pierre (Pierre, 1880). Nama author pada nama jenis basionimnya ditempatkan dalam tanda kurung (dalam hal ini "L.") dan author yang mengubahnya ditempatkan berikutnya dengan tanpa tanda kurung (dalam hal ini "Baill. ex Pierre"). Daftar mengenai penulisan author dapat dilihat pada Brummitt \& Powell (1992).

Nama ilmiah yang direvisi dapat berubah status sebagai nama basionim (nama asli yang menjadi dasar nama baru yang diterbitkan), sinonim taksonomi (konsep takson berbeda namun memiliki spesimen tipe yang sama) dan sinonim nomenklatur (konsep takson sama namun memiliki spesimen tipe yang berbeda). Nama basionim dan sinonim biasanya dicantumkan sebelum mendeskripsikan takson tertentu yang telah mengalami perubahan konsep dan dapat menunjukkan runutan sejarah perubahan nama ilmiah dari waktu ke waktu. Penamaan ilmiah terutama untuk tumbuhan, jamur dan alga, telah diatur dan disepakati secara internasional dalam "Kode Internasional Tatanama Alga, Jamur dan Tumbuhan" ("International Code of Nomenclature for Algae, Fungi, and Plants) wajib menjadi acuan oleh komunitas ilmiah. Setiap lima hingga enam tahun sekali (Turland, 2019), aturan ini diperbarui.

Nama ilmiah jenis tumbuhan terdiri dari dua kata dalam bahasa Latin atau yang di-Latinkan sehingga disebut sebagai "binomial nomenclature". Secara umum, nama latin tumbuhan dicetak miring untuk aturan penulisan dalam bahasa Indonesia seperti halnya kata asing (bukan Indonesia). Kata pertama pada binomial nomenclature mewakili kelompok marga dengan huruf pertama dicetak kapital. Kata kedua adalah nama penunjuk jenis yang diawali dengan huruf kecil (Turland dkk., 2018). Sebagai contoh, nama ilmiah bambu petung adalah Dendrocalamus asper (Schult.f.) Backer ex Heyne (Damayanto \& Riastiwi, 2018), yaitu "Dendrocalamus" adalah penunjuk marga dan "asper" adalah penunjuk jenis. Penggunaan nama penunjuk jenis yang sama dengan nama penunjuk marga tidak diperbolehkan dalam binomial nomenclature. Setelah nama jenis digunakan dalam paragraf, misalnya kelompok angur-angguran Ampelocissus elegans Gagnep. (Dalimunthe dkk., 2016), maka selanjutnya nama marga dapat disingkat dengan memakai huruf pertamanya dan nama author tidak perlu dibubuhkan sehingga menjadi $A$. elegans. Jenis yang tidak dapat ditentukan (atau tidak diketahui) namanya, misalnya pada lumut marga Dicranoloma maka akan ditulis Dicranoloma sp. (Fastanti \& Ariyanti, 2017). Untuk menunjukkan lebih dari satu jenis dalam marga tersebut maka nama jenis akan ditulis Dendrocalamus spp. (Zulkarnaen \& Andila, 2015). Pemberian nama pada tingkat di bawah 
jenis, misalnya pada tingkat varietas (dengan singkatan "var." yang berarti varietas) terdiri dari tiga kata, misalnya Bambusa vulgaris var. striata (Lodd. ex Lindl.) Gamble. Pemberian nama ilmiah secara akurat sangat penting dalam setiap bidang penelitian. Penggunaan nama ilmiah yang tidak tepat (termasuk penulisan author dan penempatan suku yang benar) dapat menjadi penyebab tidak akuratnya suatu hasil penelitian.

Suku adalah salah satu hierarki utama dalam taksonomi tumbuhan yang terletak antara bangsa dan marga. Suku dapat dibagi lagi menjadi beberapa anak suku yang merupakan peringkat menengah antara taksa suku dan marga. Nama suku secara umum diambil dari salah satu nama marga anggotanya kemudian secara umum diakhiri dengan "...ceae". Ada beberapa suku yang namanya dikonservasi, tidak mengikuti aturan tersebut, sehingga sukusuku tersebut memiliki lebih dari satu nama, sebagai contoh: Compositae (Asteraceae), Gramineae (Poaceae) dan Palmae (Arecaceae). Nama suku dimulai dengan huruf kapital dan tidak ditulis miring. Sebagai contoh, jenis Begonia sumbawaensis Girm. (Girmansyah, 2016) memiliki nama marga Begonia dan suku Begoniaceae.

\section{Revisi Taksonomi Nama Jenis dan Suku pada Tumbuhan}

Konsep jenis dan nama ilmiah jenis tumbuhan dapat mengalami perubahan sesuai dengan adanya bukti-bukti ilmiah terbaru. Perubahan nama ini juga wajib diikuti selama perubahan tersebut mengacu pada aturan penamaan tumbuhan yang berlaku saat itu. Sebagai contoh pada anggota jenis labu-labuan, Gymnopetalum pectinatum (W.J.de Wilde \& Duyfjes) Rugayah (de Wilde dkk., 2015). Sebelum direvisi, jenis ini merupakan sebuah varietas bernama Gymnopetalum integrifolium (Roxb.) Kurz var. pectinatum W.J.de Wilde \& Duyfjes (de Wilde \& Duyfjes, 2006). Revisi dilakukan karena ditemukan beberapa bukti taksonomi yang baru sehingga diputuskan bahwa varietas tersebut seharusnya diperlakukan sebagai jenis (de Wilde dkk., 2015). Dengan demikian, nama yang valid dari jenis tersebut saat ini adalah G. pectinatum.
Sementara itu, G. integrifolium var. pectinatum merupakan nama sinonim dari G. pectinatum. Sejarah penamaan jenis ini akan terekam dalam publikasi dan portal-portal berbasis data daring yang fokus pada bidang taksonomi.

Penamaan untuk tingkat suku tumbuhan secara umum mengikuti hasil klasifikasi terkini yaitu APG IV (APG, 2016) yang didasarkan pada data komprehensif termasuk data molekuler dalam melakukan pengelompokkannya. Sebagai contoh, cermai atau Phyllanthus acidus (L.) Skeels awalnya tergolong ke dalam suku Euphorbiaceae (Burger \& Huft, 1995). Kini semua jenis Phyllanthus ditempatkan ke dalam suku Phyllantaceae (Stevens, 2001).

\section{Validasi Nama Jenis dan Suku pada Tumbuhan}

Validasi nama ilmiah jenis dan suku pada tumbuhan merupakan salah satu kegiatan yang wajib dilakukan terutama dalam penelitian ilmiah yang melibatkan jenis tumbuhan di dalamnya. Validasi juga penting dalam menjaga keakuratan nama jenis dan suku pada koleksi spesimen herbarium (Girmansyah, 2014). Para ahli taksonomi tumbuhan acap kali melakukan perubahan konsep jenis akibat ditemukannya berbagai bukti ilmiah baru tentang jenis tumbuhan tersebut. Dengan demikian, nama ilmiah jenis atau suku suatu tumbuhan bersifat dinamis dan nama yang sedang diterima (accepted) saat itulah yang harus digunakan untuk menamai jenis dan suku pada tumbuhan yang diteliti. Nama-nama ilmiah yang melekat padanya dapat dijadikan sinonim [misalnya: Bambusa atra Lindl. adalah sinonim dari Neololeba atra (Lindl.) Widjaja] (Widjaja, 1997), dipindahkan antar marga [misalnya: Nastus reholttumianus Soenarko dipindahkan menjadi Chloothamnus reholttumianus (Soenarko) Widjaja] (Widjaja \& Wong, 2016) atau bahkan tata bahasa Latinnya diperbaiki (misalnya: Hetaeria alba Ridl. yang seharunya adalah Hetaeria alta Ridl.) (Turland dkk., 2018). Kenyataannya, hanya akan ada satu nama ilmiah untuk satu jenis tumbuhan yang diterima pada saat itu, untuk itulah validasi perlu dilakukan. Validasi nama jenis, salah satunya dapat dilakukan melalui laman daring seperti 
pada portal International Plant Names Index (IPNI), Tropicos dan The Plant List (Girmansyah, 2014).

\section{METODE PENELITIAN}

Penelitian dilakukan di Herbarium Bogoriense, Pusat Penelitian Biologi - LIPI pada bulan Desember 2019. Penelitian yang dilakukan adalah penelitian deskriptif yang bertujuan membuat pencandraan secara sistematis, akurat, dan faktual menganai suatu fakta (Suryabrata, 2010). Alat dan bahan yang dipergunakan dalam pengumpulan data yaitu perangkat komputer, sambungan internet, dan alat tulis. Objek dalam penelitian ini adalah tahapan validasi nama ilmiah jenis dan suku tumbuhan. Subjek penelitian berupa semua portal basis data daring yang menyediakan data nama ilmiah tumbuhan (Tabel 1). Portal tersebut kemudian diseleksi dengan beberapa kriteria yang telah ditetapkan seperti menyediakan semua nama jenis tumbuhan berpembuluh, mendata nama ilmiah tumbuhan secara global, data dimutakhirkan secara berkala, menyediakan informasi status nama ilmiah tumbuhan, menyertakan nama suku, dan beberapa informasi tambahan seperti tersedianya gambar spesimen, deskripsi jenis, peta distribusi, nama sinonim dan basionim, serta lain sebagainya. Data tersebut disusun dalam sebuah matriks pengamatan. Data yang diperoleh kemudian dianalisis dan dijabarkan secara deskriptif-naratif. Validasi nama ilmiah jenis dan suku tumbuhan melalui protolog atau publikasi revisi terkini juga dijabarkan.

\section{HASILDAN PEMBAHASAN Validasi Melalui Basis Data Daring}

Berdasarkan hasil seleksi, terdapat lima portal basis data daring penyedia data nama ilmiah tumbuhan yang memenuhi kriteria yang telah ditetapkan (Tabel 2). Portal yang tidak memenuhi kriteria sebagian besar karena tidak mendata nama tumbuhan secara global dan data jarang dimutakhirkan. Kendati demikian, tidak semua portal dalam Tabel 2 memenuhi semua kriteria yang telah ditetapkan. Informasi dalam portal tersebut saling melengkapi satu sama lainnya sehingga portal-portal ini dapat digunakan secara bersamaan dan diharapkan menghasilkan informasi yang komprehensif. Portal-portal penyedia basis data daring nama ilmiah tumbuhan tersebut dijabarkan sebagai berikut.

\section{International Plant Names Index (IPNI)}

Validasi nama-nama ilmiah tumbuhan dapat dilakukan lebih cepat, mudah dan akurat dengan memanfaatkan basis data daring yang dapat diakses secara bebas (Bennett \& Balick, 2014). International Plant Names Index atau IPNI, contohnya, adalah sebuah portal daring yang memberikan informasi tata nama untuk nama-nama ilmiah tumbuhan berpembuluh. Portal ini dapat diakses pada laman ipni.org. Portal IPNI dikelola oleh Royal Botanic Gardens, Kew dan berkolaborasi dengan The Harvard University Herbaria dan The Australian National Herbarium (IPNI, 2019). Portal IPNI menyediakan tautan (bila tersedia) ke protolog dalam artikel daring BHL serta tautan ke data taksonomi (sinonim dan distribusi) melalui portal Plant of the World Online (POWO) (powo.science.kew.org). Basis data IPNI diperoleh dari berbagai publikasi yang telah diterbitkan terkait nama ilmiah atau taksa pada tumbuhan dan dapat dilihat dalam ringkasan yang disediakan dalam menu "statistics" dalam portal IPNI.

Informasi yang ditampilkan portal IPNI, misalnya ketika mencari nama ilmiah bambu Schizostachyum purpureum Damayanto \& Widjaja (Poaceae) (Damayanto \& Widjaja, 2016), yaitu berupa nama jurnal dan tanggal publikasi, nama suku, nama dan nomor pengumpul spesimen herbarium, lokasi dan tanggal koleksi spesimen, lokasi herbarium tempat disimpannya spesimen tipe, distribusi dan sinonim. Portal IPNI menyediakan informasi mengenai sejarah perubahan nama suku, marga, jenis atau takson di bawahnya. Informasi suku pada portal IPNI dicatat berdasarkan publikasi yang tersedia (terlihat dalam ikon huruf "i”). Portal IPNI juga tidak memberikan informasi mengenai nama jenis yang diterima (accepted). Status accepted suatu nama jenis selanjutnya dapat dilihat dalam tautan menuju portal POWO yang diberikan oleh portal IPNI. Secara teknis, validasi nama 
ilmiah dalam portal IPNI wajib memperhatikan ejaan nama ilmiah yang akurat. Portal IPNI tidak akan menampilkan informasi apapun bila ejaan nama ilmiah yang dimasukkan tidak sesuai. Ada baiknya melakukan penelusuran nama ilmiah melalui laman google.com terlebih dahulu. Laman google.com akan memberitahukan bila ejaan nama ilmiah yang dimasukkan kurang tepat.

Portal IPNI selalu berupaya meningkatkan kinerja layanannya melalui masukan atau umpan balik (feedback) dari para penggunanya. Penulis (IPGPD) pernah mengirim umpan balik terkait nama jenis bambu yang sudah direvisi dan pihak pengelola portal IPNI meresponnya dengan baik dan segera. IPNI (2019) mengklaim catatan baru ditambahkan setiap hari dan pihak pengelola terus bekerja untuk meningkatkan standardisasi basis data mereka. Beberapa jurnal internasional di bidang ilmu taksonomi tumbuhan, seperti The Gardens' Bulletin Singapore dan Kew Bulletin, mewajibkan penulis menggunakan basis data IPNI dalam tulisannya (KB, 2016; GBS, 2019).

\section{Plant of the World Online (POWO)}

Portal Plant of the World Online atau POWO memungkinkan pengguna untuk mengakses informasi tentang nama ilmiah yang diterima (accepted) beserta sinonim semua tumbuhan berbiji di dunia. Portal ini dapat diakses pada laman powo.science.kew.org. POWO (2019) menyatakan bahwa portal POWO mulai dibangun pada tahun 2017 dan informasi yang disajikan belum sempurna karena kegiatan pencatatan data masih berlangsung. Pada tahun 2020, POWO diharapkan akan menjadi sumber informasi yang komprehensif. Kendati demikian, POWO (2019) menyatakan bahwa tidak semua keputusan taksonomi dalam basis data POWO berasal dari sumber yang ditinjau dari ulasan sejawat (peer-review) dan hasil kuratorial. Penelusuran nama ilmiah dalam portal POWO wajib memperhatikan ejaan nama ilmiah yang akurat.

Sebagian besar informasi yang ditampilkan dalam portal POWO mencakup nama jenis, nama suku, status nama jenis (accepted atau sinonim), pertelaan, distribusi (berupa peta), tautan menuju portal IPNI, dan bibliografi (referensi yang menyatakan diterimanya suatu nama jenis). Kendati demikian, tidak semua informasi tersebut menyertai setiap nama ilmiah yang tertelusuri. Dalam penelusuran nama jenis Dinochloa aopaensis Widjaja (Widjaja, 2009) misalnya, portal POWO tidak menyediakan nama sinonim karena jenis ini tidak pernah direvisi sebelumnya.

\section{Tropicos}

Portal Tropicos awalnya dibuat untuk penelitian internal di Missouri Botanical Garden, Amerika Serikat dan kini telah tersedia untuk komunitas ilmiah di seluruh dunia. Semua data tata nama, bibliografi dan spesimen merupakan data yang terakumulasi dalam basis data elektronik Missouri Botanical Garden selama 30 tahun terakhir. Data tersebut tersedia untuk umum pada portal Tropicos yang memiliki hampir 1,3 juta nama ilmiah, lebih dari 4,4 juta catatan spesimen, lebih dari 600 ribu gambar, dan sekitar 69 ribu nama lokal tumbuhan (Tropicos, 2019). Portal ini dapat diakses melalui laman tropicos.org.

Portal Tropicos dapat digunakan untuk menelusuri nama ilmiah ataupun nama lokal suatu tumbuhan. Menu pencarian nama tumbuhan lebih lanjut juga terdapat pilihan penyaringan (filter), sehingga mendapatkan hasil pencarian yang lebih efisien. Portal Tropicos juga memiliki menu pilihan untuk menelusuri nama jenis tumbuhan dari pencarian koleksi spesimen tumbuhan, referensi tempat terbit, proyek-proyek pendataan tumbuhan, gambar, dan beberapa menu tambahan lainnya yang mendukung pencarian jenis tumbuhan. Portal Tropicos juga menyediakan tautan langsung menuju beberapa portal terkait seperti The Plant List (theplantlist.org), IPNI (ipni.org), APNI atau Australian Plant Name Index (biodiversity.org.au), The New York Botanical Garden (sweetgum.nybg.org), Museum National d'Histoire Naturelle (coldb.mnhn.fr), Smithsonian National Museum of Natural History (collections.nmnh.si.edu), Herbarium WU, Institute of Botany, University of Vienna (herbarium.univie.ac.at), JSTOR (plants.jstor.org), SEINet (swbiodiversity.org), African Plant Database (ville-ge.ch), African 
Plants: a Photo Guide (africanplants. senckenberg.de), REFLORA (reflora.jbrj. gov.br), dan Living Collection of Missouri Botanical Garden (livingcollections.org). Pengguna wajib memperhatikan ejaan nama ilmiah yang akurat dalam penelusuran nama ilmiah pada portal Tropicos.

Portal Tropicos memberikan kode-kode tertentu dalam menentukan status setiap nama jenisnya. Kode tersebut tidak selalu muncul dalam setiap nama ilmiah yang ditelusuri. Kode tersebut antara lain, (1) tanda seru tunggal (!) yang berarti legitimate atau nama ilmiah yang sah atau diterima (accepted); (2) tanda seru ganda (!!) yang berarti nomen conservandum (bahasa Latin) atau nama ilmiah tersebut dikonservasi (nama ilmiah yang memiliki perlindungan tata nama spesifik); (3) tanda bintang tunggal $(*)$ yang berarti illegitimate atau nama ilmiah yang ada tidak sah; (4) tanda bintang ganda $(* *)$ yang berarti invalid atau nama ilmiah yang ada cacat secara taksonomi; dan (5) tanda bintang tiga kali (***) yang berarti nama nomen rejiciendum (bahasa Latin) atau nama ilmiah yang ditolak.

Ketika sebuah nama ilmiah tumbuhan ditelusuri dalam portal Tropicos, misalnya bambu Neololeba atra (Lindl.) Widjaja (Poaceae) (Widjaja, 1997), maka informasi yang disajikan berupa detail jenis (author, jurnal tempat terbit, basionim, klasifikasi dari marga hingga kelas, dan catatan sinonim), bibliografi setiap nama sinonim, referensi yang menyatakan diterima (accepted), dan distribusi. Sama seperti pada portal-portal sebelumnya, sebagian informasi belum tentu mucul untuk setiap nama jenis tumbuhan yang ditelusuri. Selain itu, portal Tropicos belum sepenuhnya dimutakhirkan oleh pengelolanya. Sebagai contoh, ketika mencari nama bambu Dendrocalamus luteus Damayanto \& Widjaja (Poaceae) yang diterbitkan Damayanto \& Widjaja (2017), jenis tersebut tidak ditemukan pada portal Tropicos meskipun dapat ditemukan di portal IPNI dan POWO.

Portal Tropicos menyatakan dengan tegas bahwa nama suku pada basis datanya mengikuti acuan APG IV (APG, 2016), sehingga menyajikan informasi nama suku yang mutakhir. Sebagai contoh, ketika nama ilmiah durian (Durio zibethinus L.) (Pandey \& Dilwakar, 2008) ditelusuri, maka portal Tropicos menyajikan informasi nama suku terkini durian, yaitu Malvaceae. Dalam pencarian yang sama, portal IPNI menyajikan nama sinonim dari suku durian yang sebelumnya yaitu Bombacaceae. Durian yang sebelumnya diketahui termasuk dalam suku Bombacaceae (Kostermans, 1958) kemudian "ditenggelamkan" dan kini semua anggota Durio tergolong dalam suku Malvaceae (Stevens, 2001).

\section{The Plant List}

The Plant List adalah sebuah portal daring yang berisi daftar semua jenis tumbuhan yang telah dipublikasi, termasuk di dalamnya yaitu tumbuhan berpembuluh (tumbuhan berbunga, berunjung, pakis dan kerabatnya) dan tumbuhan lumut. Portal The Plant List terbentuk karena adanya kolaborasi antara Royal Botanic Gardens, Kew dan Missouri Botanical Garden (TPL, 2019). Portal The Plant List dapat diakses pada laman theplantlist.org dan sangat populer digunakan oleh para peneliti dan akademisi dalam bidang ilmu taksonomi tumbuhan.

Portal The Plant List memberikan keterangan dengan jelas nama ilmiah tumbuhan yang diterima sekaligus memberikan nama suku dan tautan menuju ke semua nama sinonimnya. Meski demikian, sekitar 20\% nama ilmiah yang ada di portal The Plant List belum terselesaikan (unresolved) dan menginformasikan bahwa sumber data yang dimasukkan tidak memberikan bukti cukup untuk menentukan status sah atau tidaknya suatu nama ilmiah tumbuhan (TPL, 2019). Selain itu, TPL (2019) menginformasikan bahwa terdapat sumbersumber taksonomi lain yang dapat dipercaya dan andal untuk beberapa kelompok atau beberapa wilayah tertentu.

Penelusuran nama ilmiah salak [Salacca zalacca (Gaertn.) Voss], sebagai contoh, akan menampilkan nama jenis lengkap dengan author, nama marga dan suku, keterangan status accepted atau sinonim, nama sinonim (bila ada), tautan menuju portal IPNI, Tropicos, GBIF, JSTOR, dan beberapa portal sejenis lainnya. Portal The Plant List memiliki tingkat kepercayaan (confidence level) yang 
ditunjukkan dalam bentuk simbol bintang. Tingkat kepercayaan tertinggi ditunjukkan adanya tiga bintang yang diikuti dengan status nama jenis. Terdapat tiga buah status untuk nama jenis, yaitu accepted (nama jenis yang sah atau diterima), synonym (nama alternatif yang dahulu pernah digunakan untuk merujuk pada suatu jenis tetapi tidak diterima saat ini), dan unresolved (nama yang belum memungkinkan untuk ditetapkan statusnya dalam accepted atau synonym). Jumlah simbol bintang dapat digunakan dalam membantu mengambil keputusan saat status nama jenis yang ditampilkan berstatus unresolved. Selain itu, pengguna wajib memperhatikan ejaan nama ilmiah yang akurat dalam penelusuran nama ilmiah dalam portal The Plant List. Seperti portal lainnya, portal The Plant List tidak akan menampilkan informasi apapun bila ejaan nama ilmiah yang dimasukan tidak akurat. Namun, bila nama penunjuk marga yang dimasukan benar tetapi nama penunjuk jenisnya salah, maka portal ini akan memberikan daftar semua nama jenis yang menjadi anggota marga tersebut. Portal ini kini mulai jarang digunakan semenjak portal POWO diterbitkan.

\section{The Global Biodiversity Information Facility (GBIF) \\ Portal The Global Biodiversity Information} Facility atau GBIF memiliki tujuan memberikan akses kepada setiap orang pada basis data semua biota di dunia. Portal GBIF muncul pada tahun 1999 dari rekomendasi Biodiversity Informatics Subgroup of the Organization for Economic Cooperation and Development. Rekomendasi yang disampaikan, yaitu "mekanisme internasional diperlukan untuk membuat data dan informasi keanekaragaman hayati yang dapat diakses di seluruh dunia", dengan alasan bahwa mekanisme ini dapat menghasilkan banyak manfaat secara ekonomi dan sosial serta memungkinkan pembangunan berkelanjutan dengan memberikan bukti ilmiah yang kuat (GBIF, 2019). Portal GBIF dapat diakses pada laman gbif.org.

Informasi yang disajikan ketika menelusuri nama ilmiah tumbuhan dalam portal GBIF, misalnya melati Jasminum sambac (L.) Aiton
(Oleaceae) (Santika, 2016) adalah nama jenis lengkap dengan author, status accepted tidaknya, basionim, foto tumbuhan dan spesimen herbariumnya, peta distribusi, nama lokal (bila ada), data kemunculannya pada beberapa portal sejenis, tautan menuju portal Catalogue of Life, tingkatan taksa, dan nama sinonimnya. Portal GBIF adalah sebuah "pengumpul" (aggregator) data dari berbagai portal daring sehingga tingkat kepercayaannya perlu mendapat perhatian, terutama untuk data sebaran jenis tumbuhan yang muncul dalam peta distribusi. Secara teknis, pengguna tidak harus memperhatikan ejaan nama ilmiah yang akurat saat penelusuran nama ilmiah dalam portal GBIF. Apabila pengguna memasukan nama ilmiah dengan ejaan yang sedikit kurang tepat, maka portal GBIF akan tetap menampilkan informasi terkait yang mendekati nama ilmiah yang dimasukan tersebut.

\section{Validasi Melalui Protolog atau Publikasi Terkini}

Tumbuhan diberi nama secara ilmiah dan dipublikasikan dalam sebuah artikel ilmiah internasional atau artikel ilmiah yang dapat diakses secara luas dan banyak dibaca oleh ahli taksonomi. Publikasi tersebut semakin mudah diakses karena hampir semua jurnal menerbitkan artikelnya secara daring. Kendati demikian, banyak artikel yang menerbitkan nama ilmiah jenis tumbuhan (disebut protolog) sebelum dikenal publikasi secara daring (misalnya publikasi tahun 1800an). Protolog tersebut kini diarsipkan dan dapat diakses dengan bebas dalam laman The Biodiversity Heritage Library atau disingkat dengan BHL (biodiversitylibrary.org).

BHL merupakan sebuah konsorsium yang memiliki misi meningkatkan metodologi penelitian secara kolaboratif sehingga membuat literatur keanekaragaman hayati tersedia secara terbuka (BHL, 2018). Dari laman BHL, protolog dapat diakses sehingga validasi nama ilmiah dapat dilakukan. Sebagai contoh, untuk mengetahui kebenaran sebuah nama ilmiah bambu, yaitu Bambusa tuldoides Munro (Poaceae), maka protolog yang menerbitkan jurnal tersebut harus ditelusuri. But \& Chia (1995) menyatakan bahwa $B$. tuldoides 
diterbitkan dalam jurnal Transactions of the Linnean Society of London, tahun 1868, volume 26, halaman 93. Untuk membuktikan kebenarannya (validasi), maka artikel tersebut dapat diakses dan diunduh secara bebas melalui laman BHL sehingga validasi nama jenis tumbuhan dapat dilakukan. Selain BHL, beberapa publikasi penting terkait taksonomi tumbuhan di kawasan flora Malesia (meliputi Malaysia, Indonesia, Singapura, Timor Leste, Filipina, Papua Nugini, dan Brunei) (SteenisKruseman, 1950) dapat diakses pada versi cetak dan daring dari Flora Malesiana (floramalesiana.org) dan Prosea: Plant Resources of South-East Asia (proseanet.org).

Hasil revisi yang telah dipublikasikan dalam sebuah publikasi ilmiah, nama jenisnya akan diarsipkan. Pengarsipan dilakukan dalam portal basis data daring organisasi yang fokus pada bidang taksonomi tumbuhan seperti Herbarium Kew, Herbarium Leiden, Herbarium Missouri, dan lain sebagainya. Sebagai contoh, tanaman kapulaga dahulu dikenal dengan nama ilmiah Amomum compactum Sol. ex Maton (Zingiberaceae) (Wu \& Raven, 2000; Amxay \& Newman, 2012; Droop \& Newman, 2014). Baru-baru ini, nama ilmiah kapulaga direvisi oleh de Boer dkk. (2018) menjadi Wurfbainia compacta (Sol. ex Maton) Skornick. \& A.D.Poulsen. Dengan demikian, nama yang diterima dari kapulaga saat ini adalah $W$. compacta. Sementara itu, A. compactum mulai tahun 2018 merupakan nama sinonim dari $W$. compacta.

Validasi nama ilmiah jenis dan suku melalui portal daring merupakan cara tercepat untuk melakukan validasi, meskipun validasi melalui publikasi revisi taksonomi tumbuhan terkini merupakan cara yang paling direkomendasikan. Melakukan validasi melalui publikasi revisi taksonomi tumbuhan terkini dapat diartikan bahwa peneliti secara langsung medapatkan data dari sumber primer yang valid. Validasi berdasarkan basis data daring perlu dicek silang, sehingga nama ilmiah yang didapatkan merupakan nama yang diterima dan sah pada saat ini. Validasi dapat diawali dengan memanfaatkan portal basis data daring dan selanjutnya dikonfirmasi dengan melakukan penelusuran publikasi revisi taksonomi tumbuhan terkini. Nama ilmiah yang benar dan akurat secara taksonomi menjadi hal penting dalam pengembangan ilmu pengetahuan. Tersedianya informasi basis data daring ataupun penelusuran pustaka secara gratis diharapkan dapat memperkecil tingkat kesalahan dalam kegiatan validasi demi menghindari ambiguitas terkait kajian ilmu taksonomi (Bennett \& Balick, 2014).

\section{E. KESIMPULAN}

Validasi nama ilmiah jenis dan suku tumbuhan dapat dilakukan melalui penelusuran protolog dan publikasi hasil revisi terkini atau menggunakan portal daring seperti IPNI, POWO, Tropicos, The Plant List, dan GBIF. Validasi nama ilmiah jenis dan suku melalui portal daring merupakan cara tercepat untuk melakukan validasi, meskipun validasi melalui publikasi revisi taksonomi tumbuhan terkini merupakan cara yang paling direkomendasikan.

\section{Ucapan Terima Kasih}

Terima kasih disampaikan kepada Dr. Himmah Rustiami (Herbarium Bogoriense) atas bimbingan yang diberikan selama penulisan naskah ini. Kepada Dr. Rugayah dan Dr. Rani Asmarayani (Herbarium Bogoriense), terima kasih atas masukan yang diberikan dalam tulisan ini.

\section{DAFTAR PUSTAKA}

ACB (ASEAN Centre for Biodiversity). (2011). Training manual on plant taxonomy (dicots) in Southeast Asia. "Though the taxonomic capacity building and governance for conservation and sustainable use of biodiversity project". Jepang: Japan-ASEAN Integration Fund.

Amxay, V. L., \& Newman, M. F. (2012). A revision of Amomum (Zingiberaceae) in Cambodia, Laos and Vietnam. Edinburgh Journal of Botany, 69(1), 99-206.

Anwar, E. N., \& Wahyuni, R. (2020). Pengaruh proporsi penambahan daun katuk (Sauropus androgynus L. Merr.) terhadap sifat fisiko kimia selai lembaran apel. Teknologi Pangan: Media Informasi dan Komunikasi Ilmiah Teknologi Pertanian, 11(1), 79-87. 
APG (The Angiosperm Phylogeny Group). (1998). An ordinal classification for the families of flowering plants. Annals of the Missouri Botanical Garden, 85, 531-553.

APG (The Angiosperm Phylogeny Group). (2003). An update of the angiosperm phylogeny group classification for the orders and families of flowering plants: APG II. Botanical Journal of the Linnean Society, 141, 399-436.

APG (The Angiosperm Phylogeny Group). (2009). An update of the angiosperm phylogeny group classification for the orders and families of flowering plants. APG III. Botanical Journal of the Linnean Society, 161, 105-121.

APG (The Angiosperm Phylogeny Group). (2016). An update of the angiosperm phylogeny group classification for the orders and families of flowering plants: APG IV. Botanical Journal of the Linnean Society, 181, 1-20.

Arisandy, D., \& Triyanti, M. (2020). Keanekaragaman jenis vegetasi di Bukit Cogong Kabupaten Musi Rawas. Bioedusains: Jurnal Pendidikan Biologi dan Sains, 3(1), 40-49.

Bennett, B. C., \& Balick, M. J. (2014). Does the name really matter? The importance of botanical nomenclature and plant taxonomy in biomedical research. Journal of Ethnopharmacology, 152, 387-392.

BHL (Biodiversity Heritage Library). (2018). Biodiversity heritage library strategic plan: 2018-2020. Diakses 18 Desember, $2019, \quad$ d a r i https://about.biodiversitylibrary.org/

Brummitt, R. K., \& Powell, C. E. (1992). Authors of plant names. A list of authors of scientific names of plants, with recommended standard form of their names including abbreviations. Kew, Inggris Raya: Royal Botanic Gardens, Kew.

Burger, W. C., \& Huft, M. J. (1995). Family 113. Euphorbiaceae. In W. C. Burger (Ed.), Flora costaricensis. Fieldiana. Botany; new series, no. 36 (pp. 1-169). Chicago, IL: Field Museum of Natural History.
But, P. P. H., \& Chia, L. C. (1995). Bambusa tuldoides Munro. In S. Dransfield \& E. A. Widjaja (Eds.), Plant resousces of SouthEast Asia, no 7. Bamboos (pp. 72-74). Leiden, Belanda: Backhuys Publishers.

Chakrabarty, T., \& Balakrishnan, N. (2012). Nineteen new combinations and a new name in Breynia J.R. Forst. \& G. Forst. (Phyllanthaceae) from Indian subcontinent. Bangladesh Journal of Plant Taxonomy, 19(2), 119-122.

Chokthaweepanich, H. (2014). Phylogenetics and evolution of the paleotropical woody bamboos (Poaceae: Bambusoideae: Bambuseae). Graduate Theses \& Dissertations, Paper 13778. Ames, IA: Iowa State University, Ames.

Dalimunthe, S. H., Chikmawati, T., \& Widjaja, E. A. (2016). Revision of Ampelocissus (Vitaceae) in Sumatra. Floribunda, 5(5), 165-174.

Damayanto, I. P. G. P., \& Riastiwi, I. (2018). Ulasan: Kekinian penelitian dan pengembangan biomaterial bambu di Indonesia. Prosiding Ilmiah Nasional Seminar Lignoselulosa 2018, September 19 2018, Cibinong, Indonesia, pp. 30-39.

Damayanto, I. P. G. P., \& Widjaja, E. A. (2016). A new species of Schizostachyum (Poaceae-Bambusoideae) from Sumba Island, Indonesia. Reinwardtia, 15(2), 119122.

Damayanto, I. P. G. P., \& Widjaja, E. A. (2017). A noteworthy Dendrocalamus (Poaceae: Bambusoideae) from Sumatra, Indonesia. The Gradens' Bulletin Singapore, 69(1): 75-80.

Davis, P. H., \& Heywood, V. H. (1963). Principles of angiosperm taxonomy. Edinmburg \& London, Inggris Raya: Olyver \& Boyd.

de Boer, H., Newman, M., Poulsen, A. D., Droop, A. J., Fer, T., Hien, L. T. T., Hlavata, K., Lamxay, K., Richardson, J. E., Steffen, K., \& Leong-Skornickova. (2018). Convergent morphology in Alpinieae (Zingiberaceae): recircumscribing Amoтum as a monophyletic genus. Taxon, 67(1), 6-36. 
de Wilde, W. J. J. O., \& Duyfjes, B. E. E. (2006). Review of the genus Gymnopetalum (Cucurbitaceae). Blumea, 51(2), 281-296.

de Wilde, W. J. J. O., Duyfjes, B. E. E., \& Rugayah. (2015). Gymnopetalum pectinatum (W.J.de Wilde \& Duyfjes) Rugayah: rank of species for Gymnopetalum scabrum var. pectinatum (Cucurbitaceae). Reinwardtia, 14(2), 323324.

Droop, A. J., \& Newman, M. F. (2014). A revision of Amomum (Zingiberaceae) in Sumatra. Edinburgh Journal of Botany, 71(2), 193-258.

Fakhrizal, M., \& Saputra, K. (2020). Potensi daun katuk dalam mencegah kerontokan rambut. Jurnal Penelitian Perawat Profesional, 2(2), 193-200.

Fastanti, F. S., \& Ariyanti, N. S. (2017). The Dicranoloma (Bryophyta: Dicranaceae) of the Leuser Mountains National Park (Sumatra). Floribunda, 5(6), 200-208.

Fikri, F., \& Purnama, M. T. E. (2020). Pharmacology and phytochemistry overview on Sauropus androgynous. Systematic Review Pharmacy, 11(6), 124128.

GBIF (The Global Biodiversity Information Facility). (2019). What is GBIF? Diakses 19 Desember, 2019, dari https://www.gbif.org/what-is-gbif

GBS (The Gradens' Bulletin Singapore). (2019). Instructions for Contributing Authors. Diakses 18 Desember, 2019, dari https://www.nparks.gov.sg/sbg/research/p ublications/-/media/SBG/Documents/TheGardens-Bulletin-Singapore-Instructionsfor-Contributing-Authors-29-05-17.ashx

Girmansyah, D. (2014). Validasi, distribusi dan pemanfaatan Acanthaceae di Jawa. Berita Biologi, 13(1), 107-113.

Girmansyah, D. (2016). Three new species of Begonia (Begoniaceae) from Sumbawa Island, Indonesia. The Gardens' Bulletin Singapore, 68(1), 77-86.

IPNI (International Plant Names Index). (2019). International Plant Names Index (IPNI). Diakses 18 Desember, 2019, dari https://www.ipni.org/
IPNI (International Plant Names Index). (2020). Linnaeus, Carl (1707-1778). Diakses 9 J a nuari , $\quad 2020, \quad$ d a ri https://www.ipni.org/a/12653-1

KB (Kew Bulletin). (2016). Instructions for Authors. Diakses 18 Desember, 2019, dari http://www.springer.com/cda/content/docu ment/cda_downloaddocument/New_kewb ull_instrucsauthors $+29+12+2016 . p \bar{d} f ? S G$ WID $=0-0-45-545498-p 173750010$

KBBID (Kamus Besar Bahasa Indonesia Daring). (2020). Nama Ilmiah. Diakses 4 Februari, 2020, dari https://kbbi. kemdikbud.go.id/entri/nama\%20ilmiah

Kostermans, A. J. G. H. (1958). The genus Durio Adans. (Bombac.). Reinwardtia, 4(3), 47-153.

Kurniawan, H., Dillasamola, D., \& Rumapea, R. B. (2020). Uji afrodisiak daun katuk (Sauropus androgynus (L.) Merr pada mencit (Mus muscullus L) obesitas. Scientia Jurnal Farmasi dan Kesehatan, 10(2), 235-242.

Linnaeus, C. (1753). Species plantarum volume 1. Stockholm, Swedia: Laurentius Salvius.

Müller-Wille, S. (2020). Encyclopcedia Britannica: Carolus Linnaeus, Swedish Botanist. Diakses 9 Januari, 2020, dari https://www.britannica.com/biography/Ca rolus-Linnaeus/Classification-by-naturalcharacters

Pandey, R. P., \& Dilwakar, P. G. (2008). An integrated checklist flora of Andaman and Nicobar Islands. India Journal of Economic and Taxonomic Botany, 32(2), 403-500.

Pierre, L. (1880). Flore forestiere de la cochinchine volume 1. Paris, Prancis: Octave Doin.

POWO (Portal Plant of the World Online). (2019). About the plants of the world online portal. Diakses 18 Desember, 2019, dari http://powo.science.kew.org/about

Pullaiah, T., Bahadur, B., \& Krishnamurthy, K. (2015). Plant biodiversity. Plant Biology and Biotechnology: Plant Diversity, Organization, Function and Improvement, 1, 177-195. 
Retnowati, A., \& Rugayah. (2019). Keanekaragaman tumbuhan dan jamur Indonesia. Dalam A. Retnowati, Rugayah, J. S. Rahajoe, \& D. Arifiani (Eds), Status keanekaragaman hayati Indonesia: kekayaan jenis tumbuhan dan jamur Indonesia (pp. 1-14). Jakarta, Indonesia: LIPI Press.

Santika, Y. (2016). A conspectus of Balinese Oleaceae. Floribunda, 5(5), 175-177.

Santoso, U., Fenita, Y., Suharyanto, \& Putranto, A. M. H. (2020). Effect of Sauropus androgynus leaf extract plus turmeric powder supplementation on broiler performance. Buletin Peternakan Tropis, 1(1), 1-4.

Steenis-Kruseman, M. J. V. (1950). Malaysian plant collectors and collections. Flora Malesiana, 1(1), 1-639.

Stevens, P. F. (2001 onwards). Angiosperm phylogeny website. version 14, July 2017. Diakses 9 Januari, 2020, dari http://www.mobot.org/MOBOT/research/ APweb/welcome.html

Suryabrata, S. (2010). Metodologi penelitian. Jakarta, Indonesia: Rajawali Pers.

Syhadat, A. (2020). Skrining fitokimia daun katuk (Sauropus androgynus) sebagai pelancar ASI. Jurnal Kesehatan Ilmiah Indonesia (Indonesian Health Scientific Journal), 5(1), 85-89.

TPL (The Plant List). (2019). About the plant list. Diakses 19 Desember, 2019, dari http://www.theplantlist.org/1.1/about/

Triananinsi, N., Andryani, Z. Y., \& Basri, F. (2020). Hubungan pemberian sayur daun katuk terhadap kelancaran ASI pada ibu multipara di Puskesmas Caile. Journal of Healthcare Technology and Medicine, 6(1), 12-20.

Tropicos. (2019). Tropicos. Diakses 18 Desember, $\quad 2019, \quad \mathrm{dari}$ http://www.tropicos.org/Home.aspx

Tropicos. (2020). Linnaeus, Carl von. Diakses 8 J a n a ri, $\quad 2020, \quad \mathrm{dari}$ http://www.tropicos.org/PersonPage.aspx? personid $=9 \&$ tab $=$ names

Turland, N. (2019). The Code decoded, a user's guide to the international code of nomenclature for algae, fungi, and plants, second edition. Sofia, Bulgaria: Pensoft Publishers.

Turland, N. J., Wiersema, J. H., Barrie, F. R., Greuter, W., Hawksworth, D. L., Herendeen, P. S., Knapp, S., Kusber, W. H., Li, D. Z., Marhold, K., May, T. W., McNeill, J., Monro, A. M., Prado, J., Price, M. J., \& Smith, G. F. (2018). International code of nomenclature for algae, fungi, and plants (Shenzhen code) adopted by the nineteenth international botanical congress Shenzhen, China, July 2017. Regnum vegetabile 159. Glashütten, Jerman: Koeltz Botanical Books.

Widjaja, E. A. (1997). New taxa in Indonesian bamboos. Reinwardtia, 11(2), 57-152.

Widjaja, E. A. (2009). Three new species of Dinochloa (Poaceae, Bambusoideae) with erect culm sheath blades from Sulawesi, Indonesia. Reinwardtia, 12(5), 435-440.

Widjaja, E. A., \& Wong, K. M. (2016). New combinations in Chloothamnus (Poaceae: Bambusoideae), a genus of Malesian bamboos formerly confused with Nastus. Sandakania, 22, 37-40.

Wong, K. M, Goh, W. L., Chokthaweepanich, H., Clark, L. G., Sungkaew, S., Widjaja, E. A., \& Xia, N. H. (2016). A subtribal classification of Malesian and Southwest Pacific woody bamboos (Poaceae: Bambusoideae: Bambuseae) informed by morphological and molecular studies. Sandakania, 22, 11-36.

Wu, Z, Y., \& Raven, P. H. (Eds.) (2000). Flora of China vol. 24 (Flagellariaceae through Marantaceae). Beijing, Cina \& St. Louis, MO: Science Press \& Missouri Botanical Garden Press.

Zhou, M. Y., Zhang, Y. X., Haevermans, T., \& Li, D. Z. (2017). Towards a complete generic-level plastid phylogeny of the paleotropical woody bamboos (Poaceae: Bambusoideae). Taxon, 66(3), 539-553.

Zulkarnaen, R. N., \& Andila, P. S. (2015). Dendrocalamus spp.: bambu raksasa koleksi Kebun Raya Bogor. Prosiding Seminar Nasional Masyarakat Biodiviversitas Indonesia, 1(3), 534-538. 


\section{DAFTAR TABEL}

Tabel 1. Portal basis data daring nama ilmiah jenis dan suku tumbuhan

\begin{tabular}{lll}
\hline Nama portal & Singkatan portal & Alamat portal \\
\hline African Plant Database & - & ville-ge.ch \\
Australian Plant Name Index & APNI & biodiversity.org.au \\
Catalogue of Life & COL & catalogue.life \\
Encyclopedia of Life & EOL & eol.org \\
Flora of China & - & efloras.org \\
Integrated Taxonomic Information System & ITIS & itis.gov \\
International Plant Names Index & IPNI & ipni.org \\
Inventaire National du Patrimoine Naturel & INPN & inpn.mnhn.fr \\
National Plant Germplasm System & NPGS & npgsweb.ars-grin.gov \\
Plant of the World Online & POWO & powo.science.kew.org \\
The Global Biodiversity Information Facility & GBIF & gbif.org \\
The Plant List & - & theplantlist.org \\
Tropicos & - & tropicos.org. \\
World Checklist of Selected Plant Families & WCSP & wcsp.science.kew.org \\
\hline
\end{tabular}

Sumber: Data primer diolah tahun 2020

Tabel 2. Portal basis data daring penyedia data nama ilmiah tumbuhan yang memenuhi kriteria yang ditetapkan

\begin{tabular}{|c|c|c|c|c|c|}
\hline \multirow[b]{2}{*}{ Kriteria } & \multicolumn{5}{|c|}{ Nama/singkatan portal } \\
\hline & IPNI & POWO & Tropicos & $\begin{array}{c}\text { The Plant } \\
\text { List }\end{array}$ & GBIF \\
\hline Menyediakan nama ilmiah semua tumbuhan berpembuluh & $\sqrt{ }$ & $\sqrt{ }$ & $\sqrt{ }$ & $\sqrt{ }$ & $\sqrt{ }$ \\
\hline Mendata nama ilmiah jenis tumbuhan secara global & $\sqrt{ }$ & $\sqrt{ }$ & $\sqrt{ }$ & $\sqrt{ }$ & $\sqrt{ }$ \\
\hline Data dimuktahirkan secara berkala & $\sqrt{ }$ & $\sqrt{ }$ & $\sqrt{ }$ & $\sqrt{ }$ & $\sqrt{ }$ \\
\hline Menyediakan informasi status nama ilmiah tumbuhan & - & $\sqrt{ }$ & $\sqrt{ }$ & $\sqrt{ }$ & $\sqrt{ }$ \\
\hline Menyediakan nama suku tumbuhan & $\sqrt{ }$ & $\sqrt{ }$ & $\sqrt{ }$ & $\sqrt{ }$ & $\sqrt{ }$ \\
\hline Menyediakan gambar spesimen & - & $\sqrt{ }$ & $\sqrt{ }$ & - & $\sqrt{ }$ \\
\hline Menyediakan deskripsi jenis & - & $\sqrt{ }$ & - & - & - \\
\hline Menyediakan peta distribusi & - & $\sqrt{ }$ & - & - & $\sqrt{ }$ \\
\hline Menyediakan nama sinonim dan/atau basionim & $\sqrt{ }$ & $\sqrt{ }$ & $\sqrt{ }$ & $\sqrt{ }$ & $\sqrt{ }$ \\
\hline
\end{tabular}

Sumber: Data primer diolah tahun 2020 